HYDROGEOLOGIC INFERENCES FROM DRILLERS' LOGS AND

FROM GRAVITY AND RESISTIVITY SURVEYS IN THE

AMARGOSA DESERT, SOUTHERN NEVADA

By William J. Oatfield and John B. Czarnecki

U.S. GEOLOGICAL SURVEY

Open-File Report 89-234

Prepared in cooperation with the

U.S. DEPARTMENT OF ENERGY

Interagency Agreement DE-AI08-78ET44802

Denver, Colorado

1989 
DEPARTMENT OF THE INTERIOR

MANUEL LUJAN, JR., Secretary

U.S. GEOLOGICAL SURVEY

Dallas L. Peck, Director

For additional information write to:

Chief, Nuclear Hydrology Program U.S. Geological Survey

Box 25046, Mail Stop 421

Federal Center

Denver, C0 80225-0046
Copies of this report can be purchased from:

U.S. Geological Survey Books and Open-File Reports Section Box 25425

Federal Center

Denver, CO 80225-0425 
Abstract-1- Page

Introduction-1.-1

Purpose and scope-1 3

Previous work-0... 4

Observations from data sets- 4

Drillers' logs-1 4

Gravity data-cos 14

Vertical electric sounding (VES) resistivity data-16

Apparent alluvial thickness-_. 22

Average resistivity values for the upper 75 meters of alluvium--.-- 24

Inferred hydrogeologic framework- 26

Conclusions-1-

Selected references-0.- 28

FIGURES

Figure 1. Map showing location of study area-d

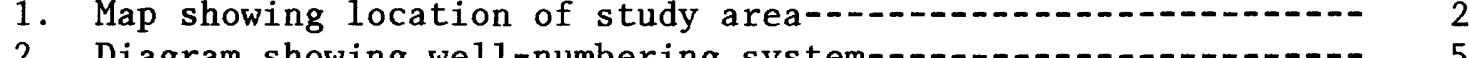

2. Diagram showing well-numbering system-10 5

3. Diagram showing schematic representation of a drillers' log-- 7

4. Hydrogeologic section showing schematic representation of drillers' logs, alluvial thickness based on electrical data, and static water level-

5. Map showing fraction of coarse-grained sediments in the upper alluvium-.-1..-

6. Diagram of semivariogram showing variation in fraction of coarse-grained sediments with distance between observation points--..-

7. Map showing fraction of coarse-grained sediments based on drillers' logs, interpolated using universal kriging--.-.-

8. Map showing values of standard deviation for fraction of coarse-grained sediments based on drillers' logs, interpolated using universal kriging-...

9. Histogram of the raw observed values of the fraction of coarse-grained sediments obtained from drillers' logs-..---

10. Map showing Bouguer gravity in study area-c.

11. Map showing center points of Schlumberger array vertical electric soundings--.-

12. Graph showing typical vertical electric sounding profile showing interpolated resistivity compared to depth-...--

13-17. Maps showing:

13. Sodium concentrations in ground water-a

14. Apparent alluvial thickness from vertical electric sounding resistivity surveying-.....

15. Depth to ground water-ar.

16. Average transverse resistivity based on vertical electric sounding profiles-...

17. Average transverse-resistivity values for the upper 75 meters of the alluvium as represented by the resistivity-depth profiles- 


\section{CONVERSION FACTORS}

Metric (International System) units in this report may be converted to inch-pound units by use of the following conversion factors:

Multiply SI units

meter $(\mathrm{m})$

kilometer $(\mathrm{km})$

hectare (ha)
By

3.281

0.6214

2.471
To obtain inch-pound units

foot

mile

acre

The following terms and abbreviations also were used in this report:

kilometer per second $(\mathrm{km} / \mathrm{s})$

ohm-meter (ohm-m)

millimoles per liter $(\mathrm{mmol} / \mathrm{L})$ 


\section{HYDROGEOLOGIC INFERENCES FROM DRILLERS' LOGS AND FROM GRAVITY AND RESISTIVITY SURVEYS IN THE AMARGOSA DESERT, SOUTHERN NEVADA}

By William J. Oatfield and John B. Czarnecki

\section{ABSTRACT}

The Amargosa Desert of southern Nevada, in the Basin and Range province, is hydraulically downgradient from Yucca Mountain, the potential site of a repository for high-level nuclear waste. Ground-water flow paths and flow rates beneath the Amargosa Desert are controlled in part by the total saturated thickness and the hydraulic properties of basin-fill alluvial sediments. Drillers' logs of water wells completed in alluvium were analyzed to help characterize the hydrogeologic framework underlying the Amargosa Desert. Fractions of coarse-grained sediments, calculated from each of these logs, were contoured using a universal-kriging routine to interpolate values. Results from a previous electrical sounding survey also were contoured, including the estimated depth to Paleozoic (?) basement rocks. The vertical electric sounding results were obtained from individual depth-to-resistivity profiles, from which the average resistivity of the total profile and the resistivity of the upper 75 meters were calculated. The distribution and variations in average resistivity of the total depth correlated reasonably well with the distribution of variations in regional gravity. Patterns of contours of the resistivity of the upper 75 meters of alluvium were similar to patterns of regional contours of the predominant cation (sodium) in ground water. Gravity lows correspond in some places to the presence of lacustrine, eolian, or marsh surface deposits, which may function as barriers to groundwater flow. Gravity lows also correspond to areas with thick basin-fill sediments, which was corroborated by depth-to-basement data determined from vertical electric soundings. Depths to Paleozoic (?) basement rocks may be as much as 1,600 meters based on data from the resistivity survey, which were corroborated in part by seismic-refraction survey data. Small variations exist in the percentage of the basin fill that is saturated. The unsaturated zone is always less than 15 percent of the alluvial column. Analysis of depth-to-water and hydrochemical data, in conjuction with average resistivity data for the upper 75 meters of alluvium, suggests a hydrologic barrier near the center of the Amargosa Desert.

\section{INTRODUCTION}

The Amargosa Desert (fig. 1) is located hydraulically downgradient from Yucca Mountain, the potential site of a high-level nuclear-waste repository. As part of a study to characterize the regional ground-water flow system in the vicinity of Yucca Mountain, drillers' logs and geophysical surveys were analyzed to characterize further the hydrogeologic framework underlying the Amargosa Desert. 


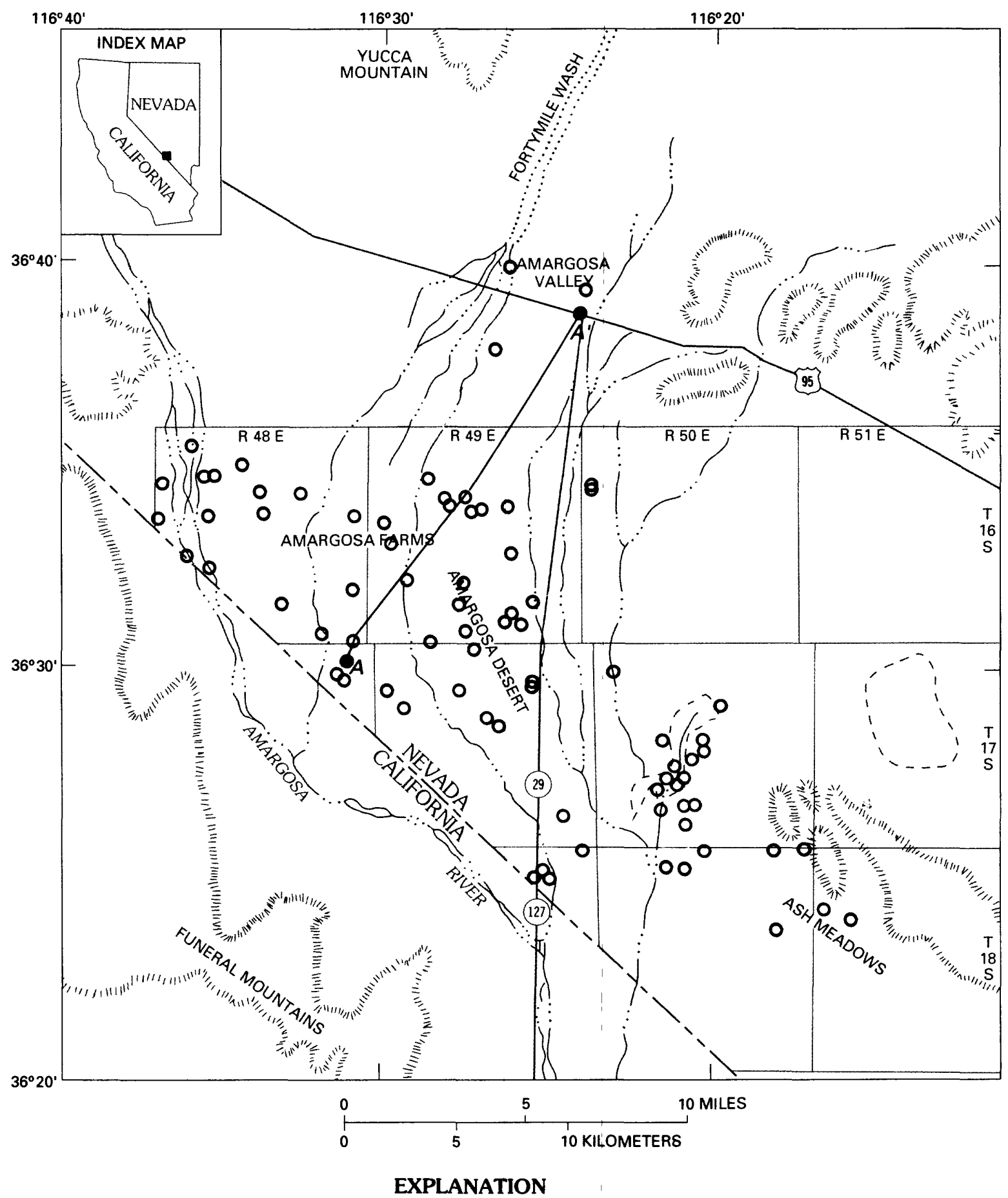

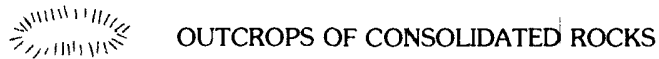

$\because-\cdots$, MARSH OR PLAYA AREA

- WATER WELL WHERE DRILLERS' LOG WAS RECORDED AND USED IN THIS STUDY

$\overbrace{A} A^{\prime}$ GEOLOGIC SECTION $A \cdot A^{\prime}$-Shown on

Figure 1.--Location of study area. 
The Amargosa Desert is an alluvial basin along the Nevada-California border, whose provenances are Tertiary volcanics near Yucca Mountain to the north, and Precambrian and Paleozoic sedimentary rocks from mountains to the southeast and southwest. The desert floor slopes gently southward with low hills widely scattered across the mostly flat terrain. Very few outcrops of Mesozoic aged rocks occur in the region. Precambrian and possibly Paleozoic rocks underlie the Tertiary and Quaternary basin fill. The desert is between the Furnace Creek Fault Zone and the Walker Lane Shear Zone, which have been tectonically active during the Cenozoic Era.

Data used in this study were collected principally during several surface-geophysical studies. Agricultural development of the Amargosa Farm area and ranching in the Ash Meadows area have resulted in the drilling and logging of many water wells, from which data also were available. Depths to ground water decrease southward from Yucca Mountain. This study uses combined information from these sources to refine understanding of the groundwater-flow system, under Interagency Agreement DE-AI08-78ET44802 with the U.S. Department of Energy.

\section{Purpose and Scope}

This report describes the results of analysis of drillers' logs, recorded from wells drilled in the southeastern Amargosa Desert, in conjunction with the results of analysis of surface geophysical surveys conducted in the same area. The study originally was performed to compile and analyze data from drillers' logs of wells constructed in the Amargosa Desert alluvium. The data were for application to a numerical flow model of regional ground-water flow in an area that includes Yucca Mountain. This numerical model has evolved over several years, based on limited specific knowledge of the regional hydrostratigraphy of the ground-water flow system. To improve the conceptual model, a search was made for information that would help delineate areas that had substantially different values of transmissivity within the Amargosa Desert. These data came from various sources: (1) Drillers' logs of water wells; (2) a vertical electric sounding (VES) resistivity survey (Greenhaus and Zablocki, 1982); (3) a gravity survey (Healey and others, 1980); (4) an aeromagnetic survey (Greenhaus and Zablocki, 1982); and (5) seismic-refraction surveys across the northern Amargosa Desert (W.D. Mooney and S.G. Schapper, U.S. Geological Survey, written commun., 1989). Hydrochemical data from ground-water samples from the Amargosa Desert (Claassen, 1983) were used with the analysis of the VES data.

The stratigraphy of the alluvial sediments of the desert basin was needed to further the interpretation of ground-water flow paths through this material. The delineation of potential barriers to ground-water flow, such as fine-grained sediments, other less-permeable strata, or faults through the alluvium, also were potential goals of this study. One such feature, the Tertiary confining unit mentioned by Naff (1973) was particularly significant. The plan of investigation for discovering more detail about these or newly ascertained structures was first to analyze individual past studies (generally based on single types of data or single approaches) for their particular contributions to understanding basin structure. Joint qualitative analysis of the data types, together, then would proceed in order to determine the significance of features discovered in these past studies. 


\section{Previous Work}

Interpretation of the data presented in this report was based, in part, on the work of various authors. Walker and Eakin (1963), Denny and Drewes (1965), Naff (1973), Naff and others (1974), Winograd and Thordarson (1975), Carr (1984), and Czarnecki and Waddell (1984) all reported on ground-water flow and geology in the area. Healey and Miller (1971), Greenhaus and Zablocki (1982), and W.D. Mooney and S.G. Schapper (U.S. Geological Survey, written commun., 1989) provide geophysical descriptions. Because this report is a synthesis of previous efforts, their contributions are essential to the results. Naff's (1973) careful interpretive work on a small part of this study area was particularly valuable.

\section{OBSERVATIONS FROM DATA SETS}

Commercial drillers' logs from wells in this area generally are insufficient for detailed stratigraphic analysis. Data from selected logs were plotted in a manner to differentiate the stratigraphy at each drill hole. This stratigraphy then was used to correlate similar lithologic units, such as sequences of precipitated rocks, fine-grained sediments, and coarse-grained sediments.

Because almost none of the drillers' logs were from boreholes that penetrated into basement [Precambrian (?) or Paleozoic(?)] rock, other data were needed to estimate the thickness of the alluvium and the importance of the conclusions that could be derived from the logs. These additional data also provide information on the nature of the basement rock. A VES survey of the Amargosa Desert (Greenhaus and Zablocki, 1982) area provided the most useful data. Gravity data (Healey and others, 1980) collected throughout many years and data from seismic-refraction surveys (W.D. Mooney and S.G. Schapper, written commun., 1989) in the northern part of the Amargosa Desert constituted additional potentially corroborative data.

The wel1-numbering system (fig. 2) used in this report indicates the location of wells within the official rectangular subdivision of public lands. The first two segments of a number designate the township (north or south) and the range (east or west). The third segment is the section number, followed by three letters and a numeral, which indicate the quarter section (64.8hectare (ha) tract), the quarter quarter section (16.2 ha tract), the quarter quarter quarter section (4.0-ha tract), and serial number (if any) of the well within the tract. Quarter sections are designated by the letters a, b, c, and $d$ in counterclockwise order from the northeast quarter of each section.

Within quarter sections, 16.2 ha and 4.0-ha tracts are lettered in the same

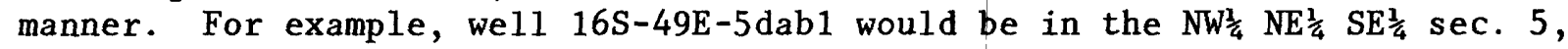
T.16S., R.49E. and would be the first well inventoried in that tract.

\section{Drillers' Logs}

The locations of water wells where drillers' logs were recorded and used in this study are indicated in figure 1. A drillers' $\log$ is a record of the drilling activity during the construction of a drillhole, including a generic description of lithology and thicknesses, based on rock cuttings removed from 


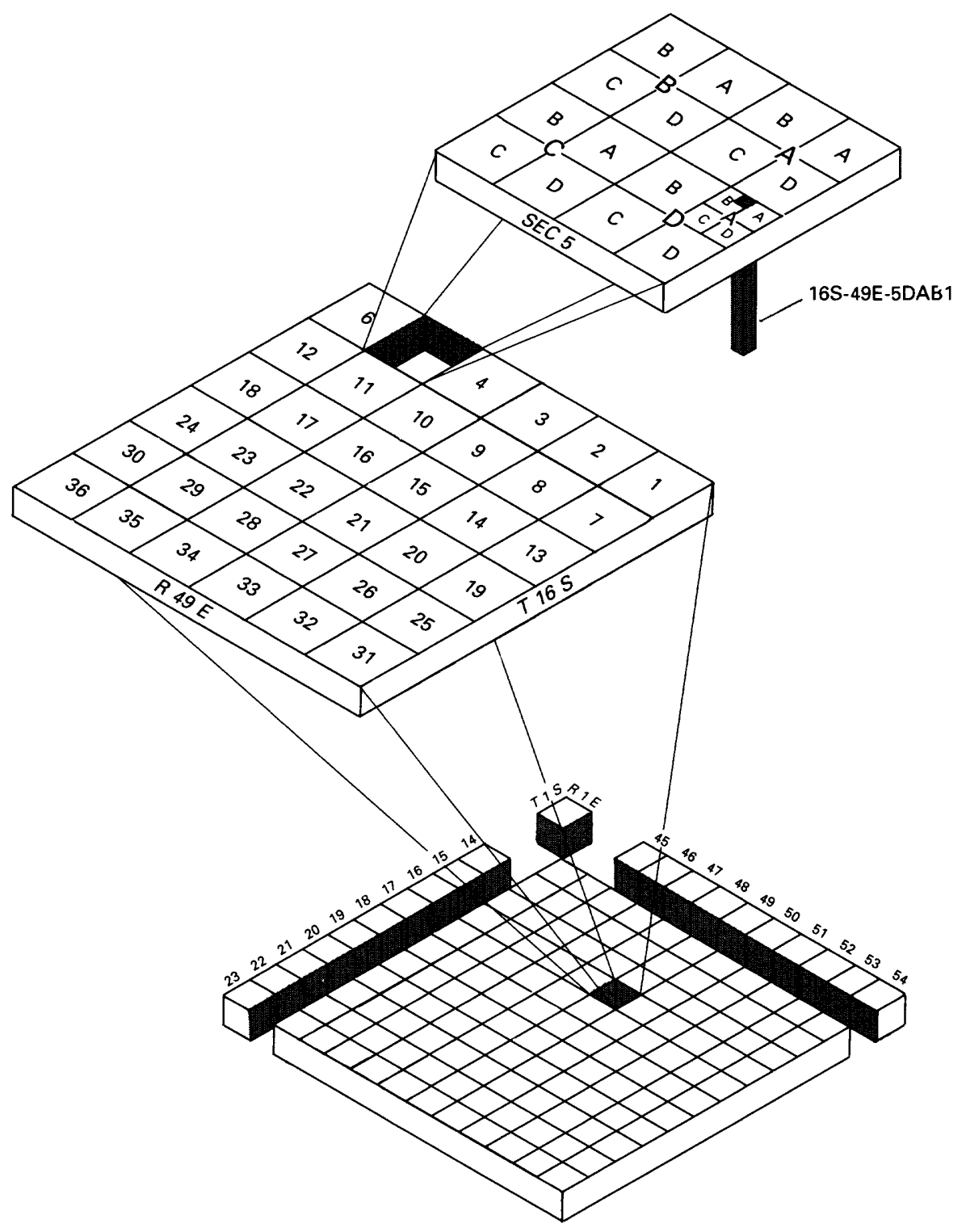

Figure 2.--We11-numbering system. 
the borehole during drilling. Commercial drillers' logs were compared to logs that had some quality control, and those determined by the author as not acceptable were rejected. Most water wells were drilled to depths of about 50 to $75 \mathrm{~m}$. However, logs of very shallow ( $25 \mathrm{~m}$ or less) dry holes, which were the most numerous of the holes represented in the source data, would bias any subsequent analyses by overrepresenting the shallowest remaining materials. A11 logs of boreholes less than $25 \mathrm{~m}$ deep were therefore excluded.

Stratigraphy based solely on the remainder of the drillers' logs leaves many uncertainties concerning the hydrogeologic framework in the area. These are substantiated by the fact that no cross section of this area has a single unit that is horizontally continuous. Worse, logs of holes clustered in very small areas indicate few, if any, such units. This holds true even when considering units from these clustered holes to be correlated if they have the same drillers' descriptions above and below the units being compared, regardless of the thicknesses of the compared units. Therefore, drillers' log descriptions were reevaluated in an attempt to make the descriptions more useful.

An example of the calculation of the fraction of coarse-grained sediments from a drillers' $\log$ is shown in figure 3 . This schematic representation of a drillers' $\log$ shows the position of land surface as the top horizontal line; an arbitrary vertical straight line separates sandy clay and finer grained sediments to the left from clayey sand and coarser grained sediments to the right, all scaled for depth. The fraction of coarse-grained sediments was calculated from each of these schematic representations by summing the thicknesses of each coarse-grained layer and dividing by the total depth of the drillhole.

A series of these schematic representations is shown in the cross section in figure 4. This cross section (the line of section $A-A^{\prime}$ in fig. 1) shows thick alluvial sediments overlying an inferred Paleozoic (?) basement; this thickness is based on the contoured results from electrical surveys (see the "Alluvial Thickness" section). A general trend of finer to coarser sediments, from left to right, is apparent from these schematic representations; however, distinct, correlatable units are absent, even for closely spaced drillholes.

The apparent lack of stratigraphic continuity may indicate that: (1) The alluvium is too heterogeneous to characterize it by grain size; (2) the grainsize divisions shown in figure 3 are too fine to enable correlation of units; or (3) the drillers' logs do not contain enough information about the stratigraphy. Possibly, all three conditions are true.

The fraction of coarse-grained sediments derived from drillers' logs is contoured in figure 5. A general relation is indicated where coarser sediments in the northwestern part of the study area grade toward finer sediments in the southeastern part of the study area. Coarser sediments occur predominantly along the upgradient parts of stream channels. Along the lower Amargosa River, fine-grained sediments (primarily freshwater limestone) predominate in the upper part of the stratigraphic section. These limestones may be the product of ground-water discharge during wetter periods in the past (Hay and others, 1986). 


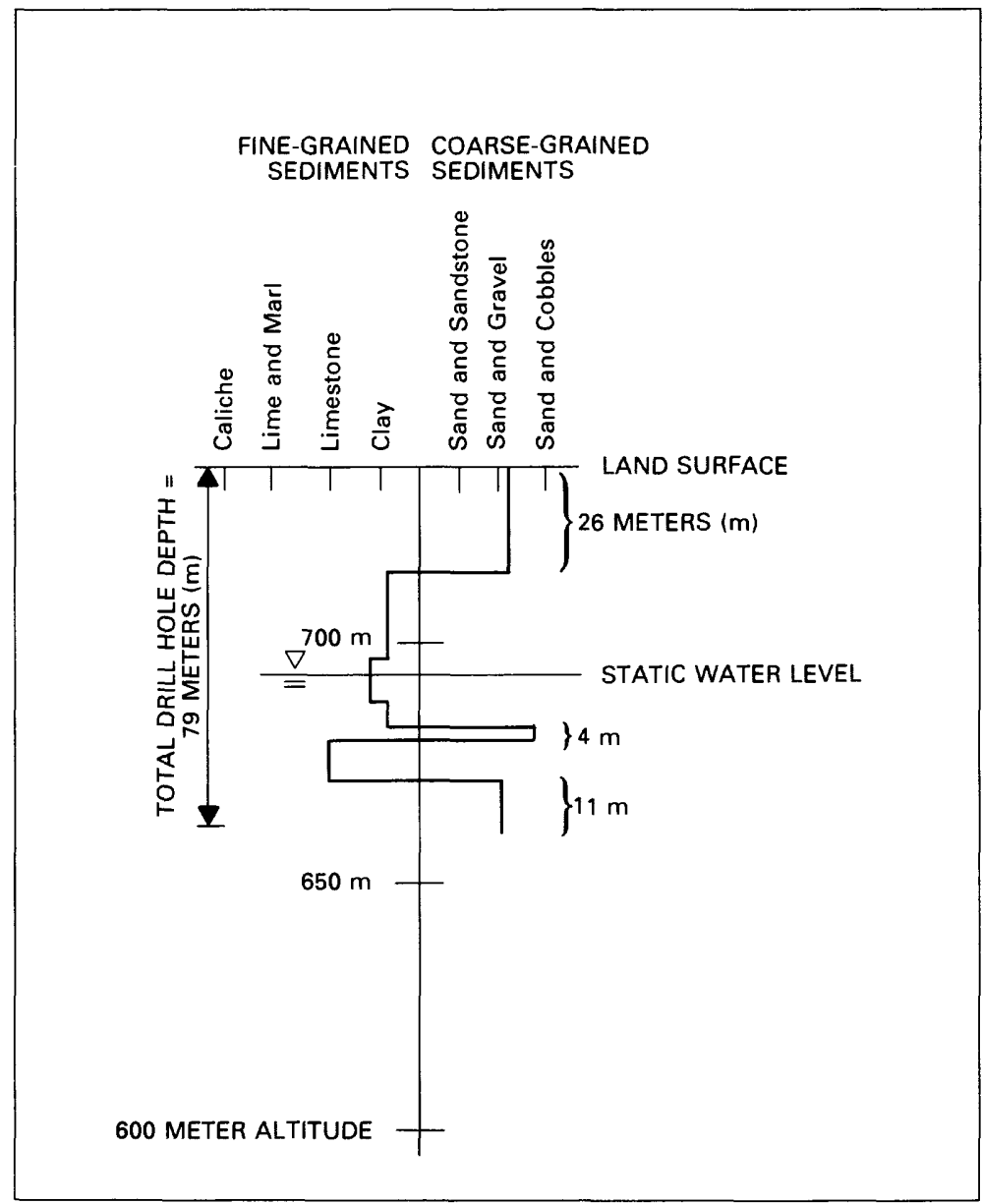

$$
\begin{aligned}
\text { FRACTION OF COARSE-GRAINED SEDIMENTS } & =\frac{\begin{array}{c}
\text { SUM OF THICKNESS OF } \\
\text { COARSE-GRAINED SEDIMENTS }
\end{array}}{\text { TOTAL DRILL HOLE DEPTH }} \\
& =\frac{(26+4+11) \mathrm{m}}{79 \mathrm{~m}} \\
& =0.52
\end{aligned}
$$

Figure 3.--Schematic representation of a drillers' log. 


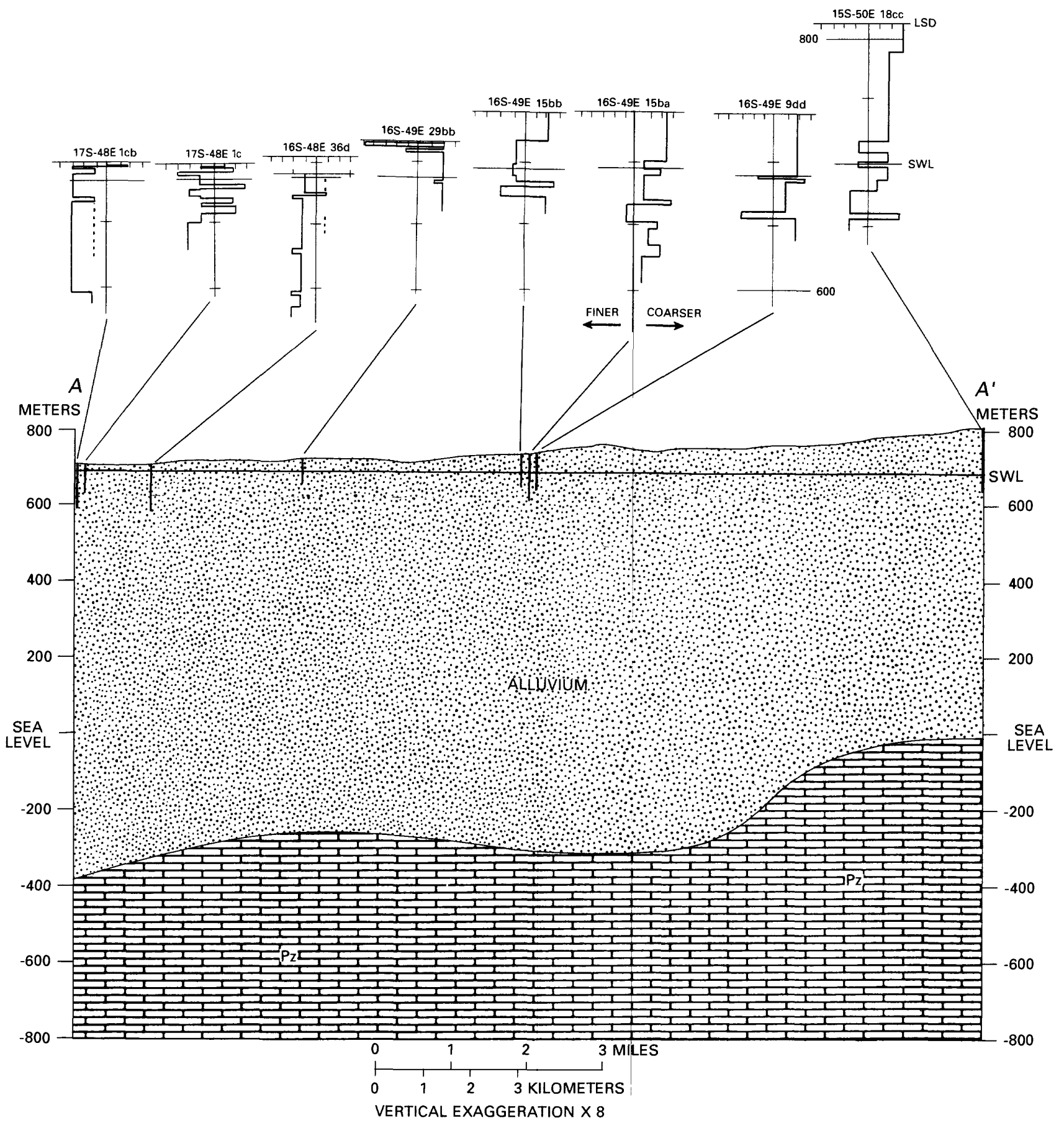

\begin{tabular}{cl}
\multicolumn{2}{c}{ EXPLANATION } \\
PZ & PALEOZOIC? ROCKS \\
SWL & STATIC WATER LEVEL \\
LSD & LAND-SURFACE DATUM \\
BSE ICb & DRILL HOLE LOCATION
\end{tabular}

Figure 4.--Hydrogeologic section showing schematic representation of drillers' logs, alluvial thickness based on electrical data and static water level. (Electrical data from Greenhaus and Zablocki, 1982. Location is line of section $A-A^{\prime}$ in fig. 1.) 


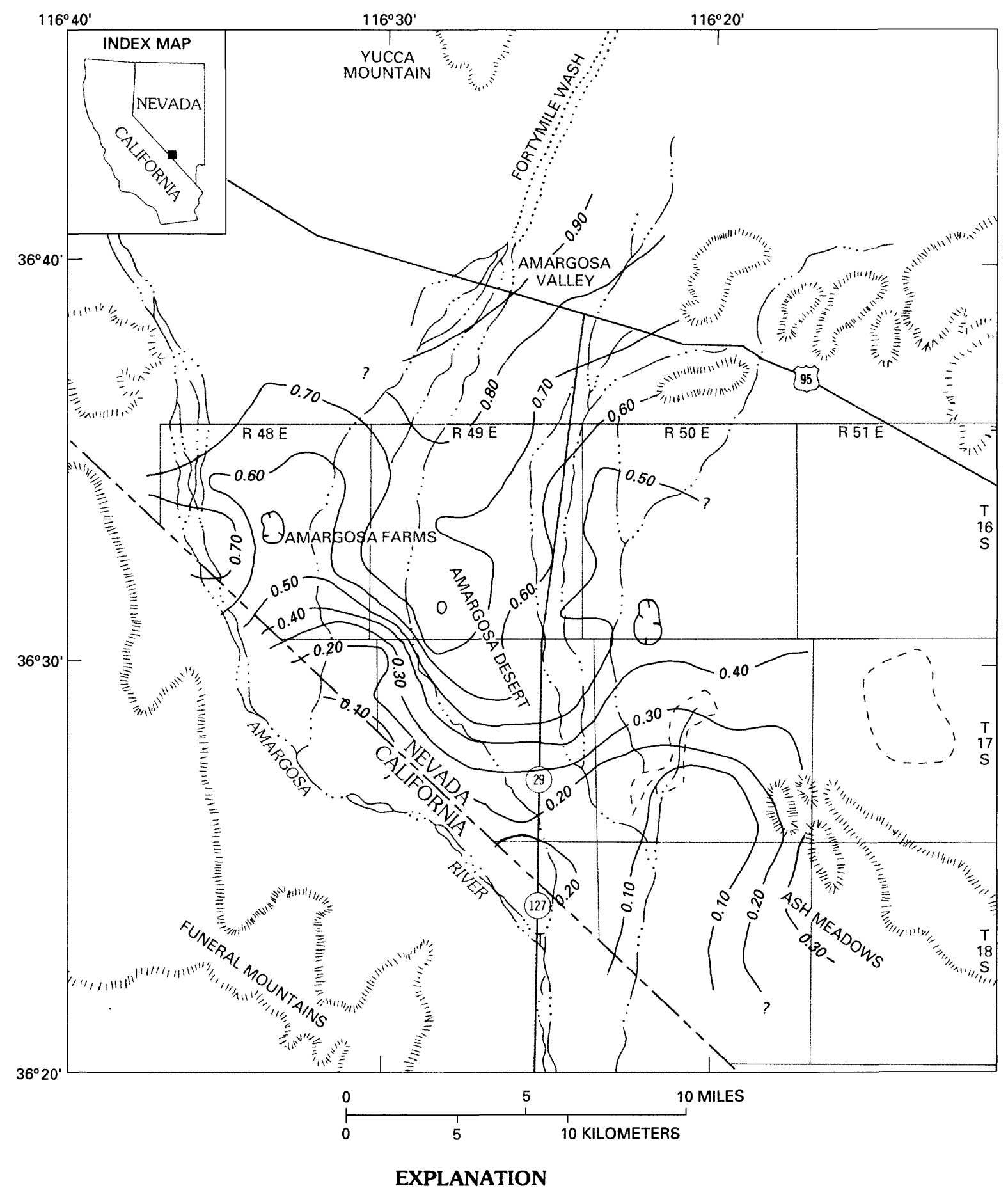

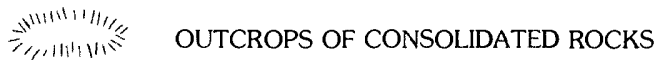

:- - - MARSH OR PLAYA AREA

0.30 LINE OF EQUAL FRACTION OF COARSE-GRAINED SEDIMENT, BASED ON DRILLERS' LOGS-Interval is 0.10

Figure 5.--Fraction of coarse-grained sediments in the upper alluvium. 
To better understand the distribution and variance of the fraction of coarse-grained sediments estimated from drillers' logs, these data were analyzed using a semi-variogram and universal-kriging computer program (Skrivan and Karlinger, 1980). This program was used to obtain interpolated values of the fraction of coarse-grained sediments, while retaining the values obtained at the observation points themselves.

A semi-variogram, showing the variation in the fraction of coarse-grained sediments with distance between observation points is shown in figure 6 . A theoretical spherical semi-variogram was chosen to best fit the data. From this theoretical semi-variogram, estimates of the range (a), the nugget (c), and the sill $(w+c)$ were obtained. Three criteria were used to obtain the optimal variable values of the spherical theoretical semi-variogram:

(1) the kriged average error, $\frac{1}{n} \sum_{i=1}^{n}\left(z_{i}-\hat{z}_{i}\right)$;

(2) the kriged mean square error, $\frac{1}{n} \sum_{i=1}^{n}\left(\left(z_{i}-\hat{z}_{i}\right)^{2}\right)^{\frac{1}{2}}$; and

(3) the kriged reduced mean square error, $\frac{1}{n} \sum_{i=1}^{n}\left(\left(z_{i}-\hat{z}_{i}\right) / \hat{\sigma}_{i}{ }^{2}\right)^{\frac{1}{2}}$,

where $\mathrm{n}=$ the number of observations,

$z_{i}=$ the $i$ th observation,

$\hat{z}_{i}=$ the kriged estimate of the ith observation, and

$\hat{\sigma}_{i}=$ the standard deviation of the kriged estimate.

A reasonably "good fit" is obtained when (1) approaches zero, (2) approaches zero, and (3) approaches one. The final form of the theoretical spherical semi-variogram yielded a kriged average error of 0.004 ; a kriged mean square error of 0.2011 ; and a kriged reduced mean square error of 1.0035 . Refinement of these semi-variogram variables was made by repeated trial-and-error computer runs that produced the following values: range, $4.1 \mathrm{~km}$; nugget, 0.024 ; and sill, 0.104 .

Estimates of the fraction of coarse-grained sediments were made throughout the study area using observed values in conjunction with the optimal variable values of the theoretical spherical semi-variogram. These kriged interpolated estimates are shown in figure 7. Correlation between the kriged interpolated estimates shown in figure 7 and the raw observations shown in figure 5 generally is acceptable. The major trends in the data are still present, although the kriged surface is smoothed considerably. An advantage to interpolating estimates using kriging is that in addition to knowing the interpolated values at points (which can be arbitrarily specified within the region of interest), the standard deviation, or uncertainty in the estimate also is known (fig. 8). As expected, standard deviation values are smallest near observed data points, and are estimated to be almost equal to the 


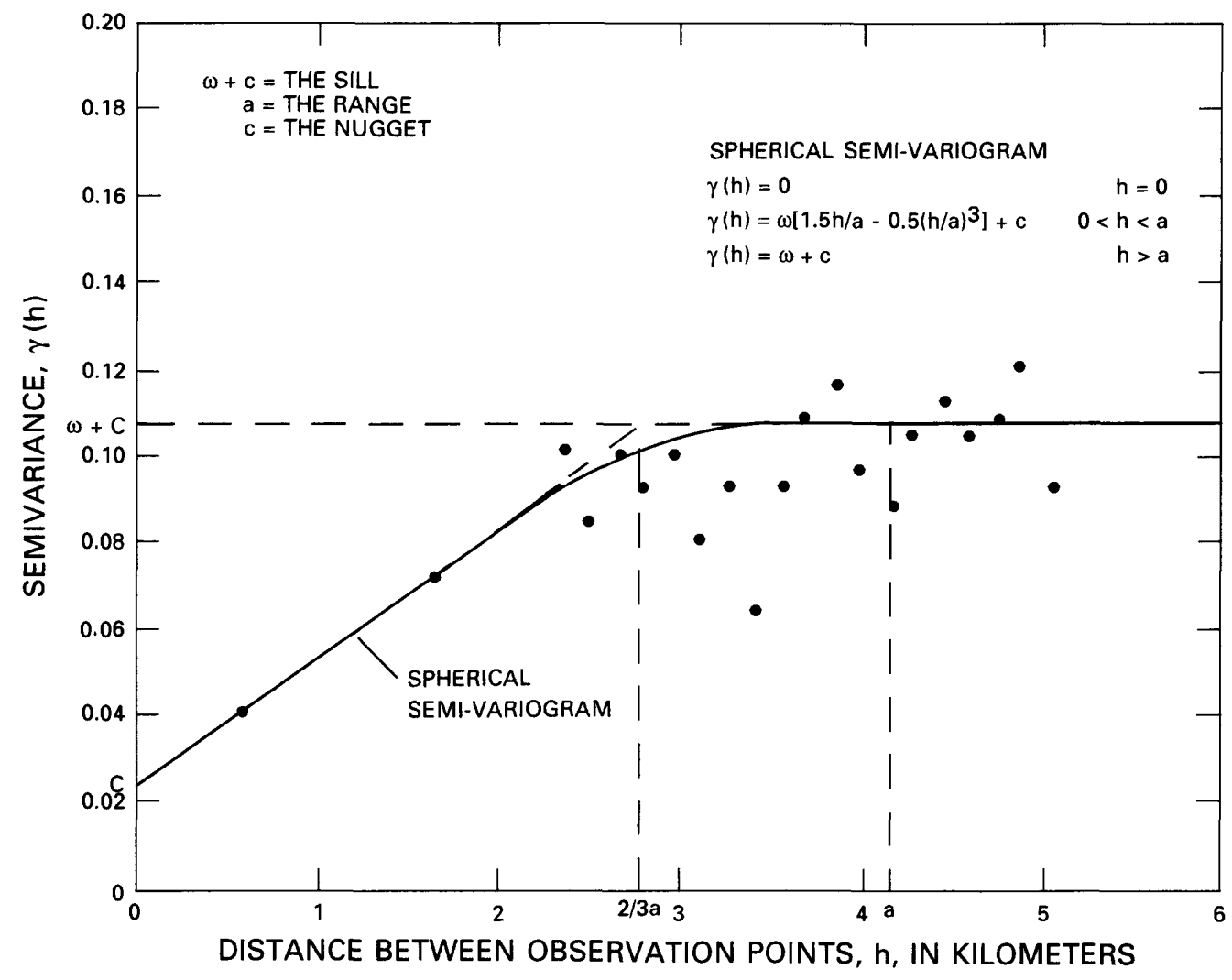

Figure 6.--Semivariogram showing variation in fraction of coarsegrained sediments with distance between observation points.

standard deviation of the total data population (0.32) where data points are absent. A histogram of the raw observed values of the fraction of coarsegrained sediments is shown in figure 9. This histogram shows a fairly uniform distribution of observed values.

A major problem with combining grain-size and geophysical data in interpretations of stratigraphy is the scarcity of drillers' logs from deep wells. One good-quality log is available near Lathrop Wells and indicates unconsolidated sediments to a depth of almost $500 \mathrm{~m}$. A few $10 \mathrm{gs}$ to depths of 200 to $300 \mathrm{~m}$ are from a marsh area (T.17S., R.50E.); they record substantial clay layers interbedded with occasional limestone. The deepest well, logged with considerable care, is about $600 \mathrm{~m}$ deep and is near the State line in T.17S., R.49E. This well penetrates consolidated rock from near the surface to the total depth of the borehole. It also is approximately along the trend of Naff's postulated Tertiary confining bed (Naff, 1973, p. 26). These few deep wells seem to expose a trend of increasing consolidation in sediments from north to south. No drillholes in the study area provided rock samples that were analyzed for bulk density. However, the limited information about consolidation is useful in inferring conclusions about porosity from gravity data. 


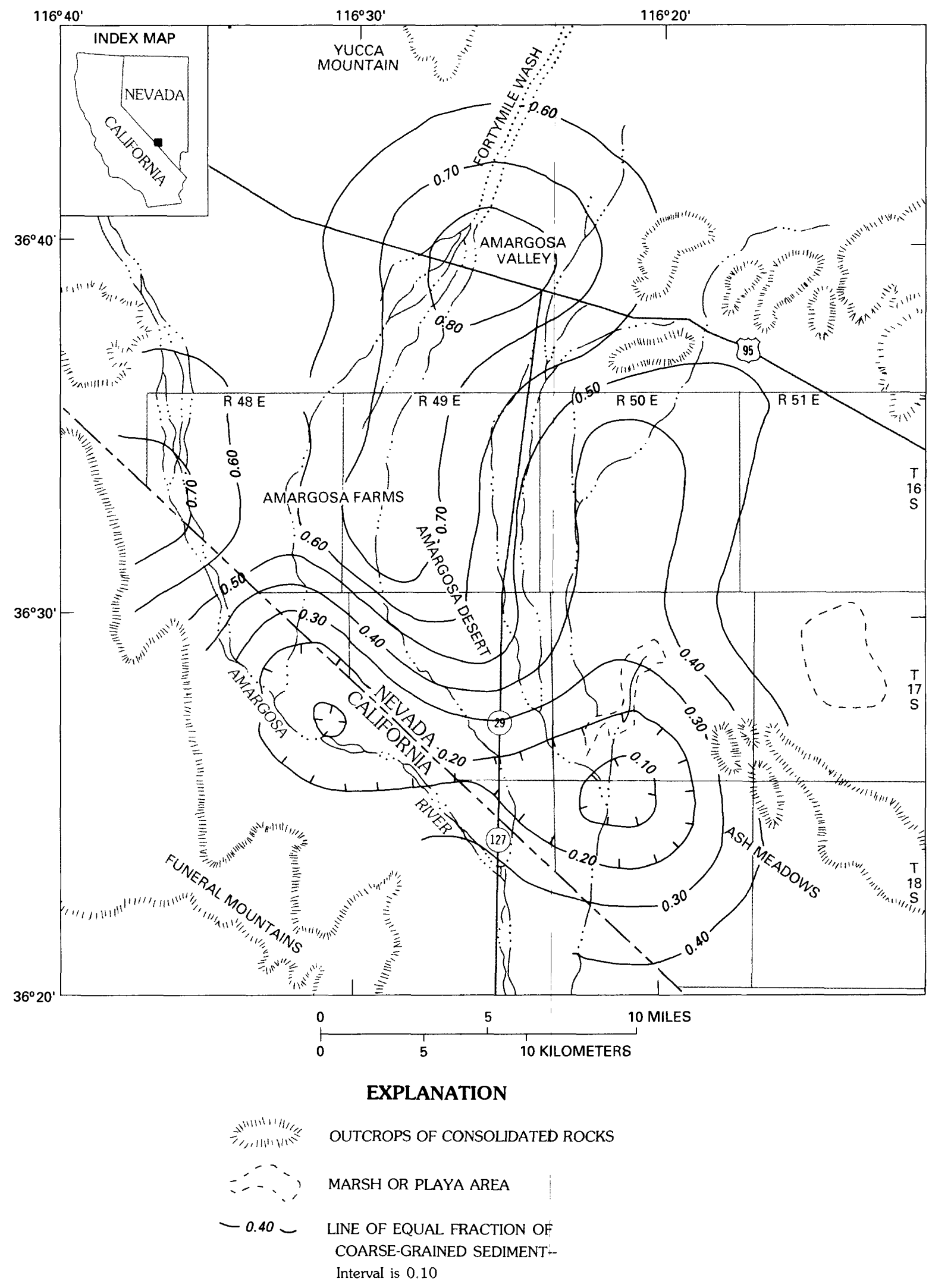

Figure 7.--Fraction of coarse-grained sediments based on drillers' logs, interpolated using universal kriging. 


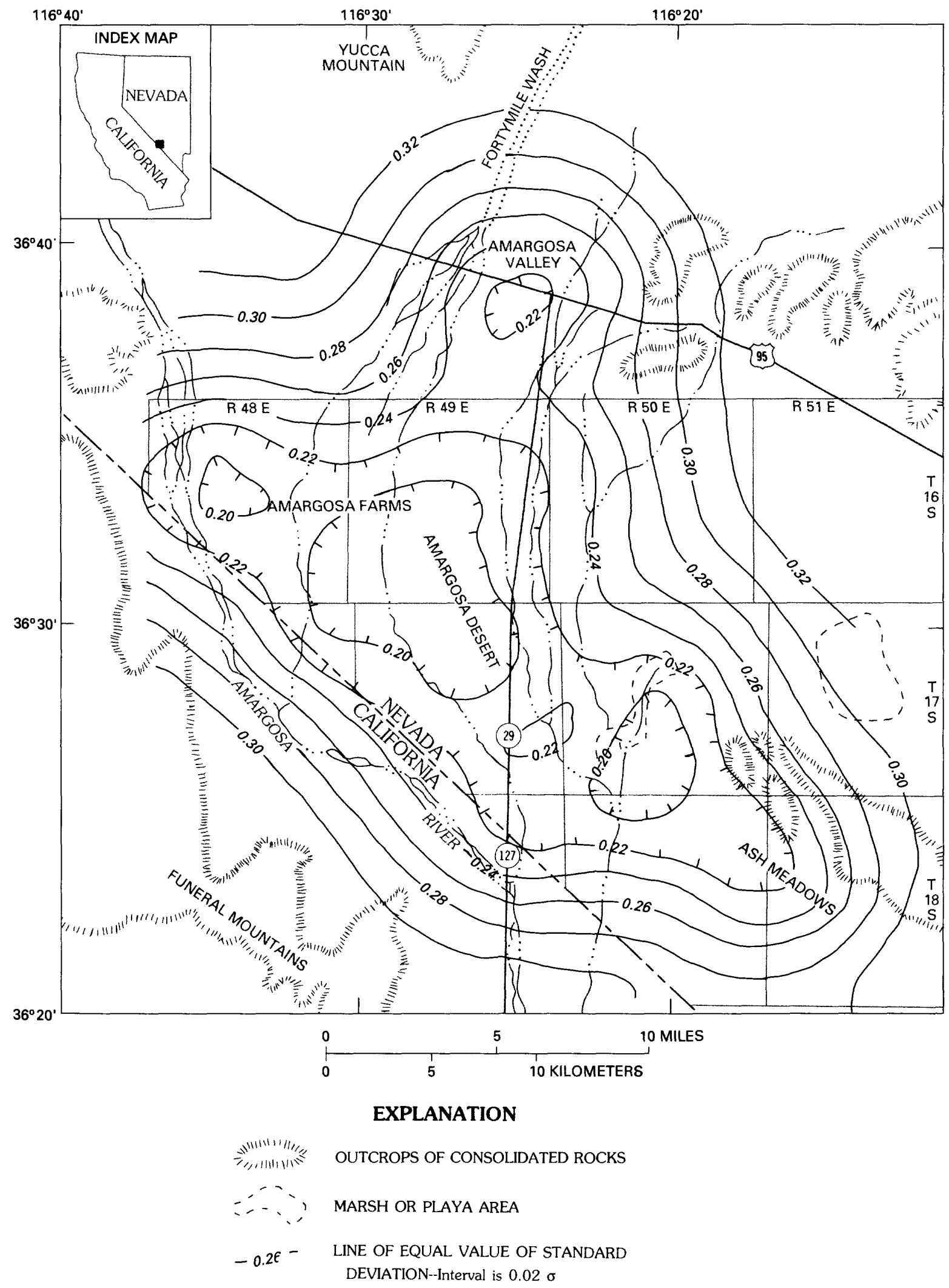

Figure 8.--Values of standard deviation for fraction of coarse-grained sediments based on drillers' logs, interpolated using universal kriging. 


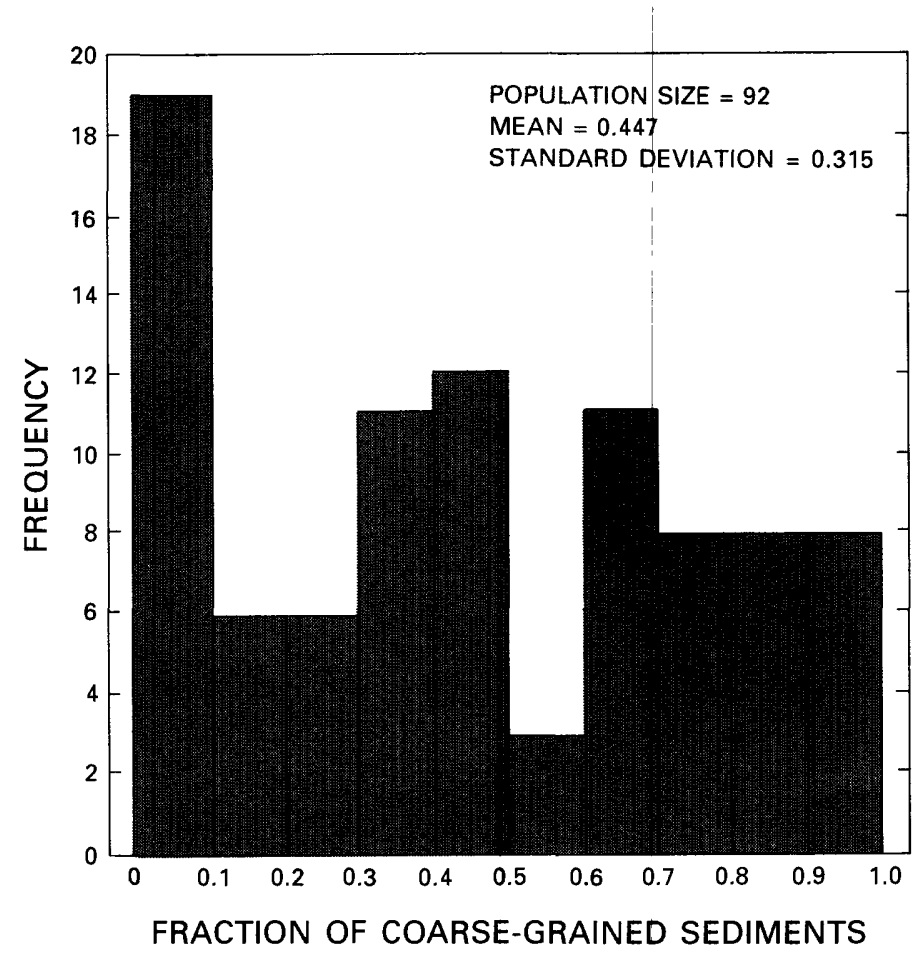

Figure 9.--Histogram of the raw observed values of the fraction of coarse-grained sediments obtained from drillers' logs.

\section{Gravity Data}

The general structure of the basin was determined first from gravity data assembled by Healey and Miller (1971). From their calculated Bouguer values, they interpreted the presence of thick sediments, a steep normal fault in the basement rocks beneath the center of the study area, and large displacements of the basement near outcrops of Paleozoic rocks in the southern part of the study area. Contours of regional gravity data are shown in figure 10 . This map shows a general decrease in gravity away from the Funeral Mountains. Five gravity lows occur in the study area (L1-L5); in general, these lows probably indicate the presence of thick deposits of alluvium (see the "Apparent Alluvial Thickness" section) composed of marsh, lacustrine, and eolian deposits. An exception to this pattern is gravity low, L4, where drillers' logs record the presence of fully indurated limestone.

Gravity data show some relation to the fraction of coarse-grained sediments based on drillers' logs (fig. 5). Coarse-grained sediments are found at gravity low L1, with finer grained sediments found at L3, L4, and L5 (fig. 10). Finer grained sediments tend to exhibit larger values of porosity (Freeze and Cherry, 1979, p. 37) and correspondingly smaller bulk densities. 


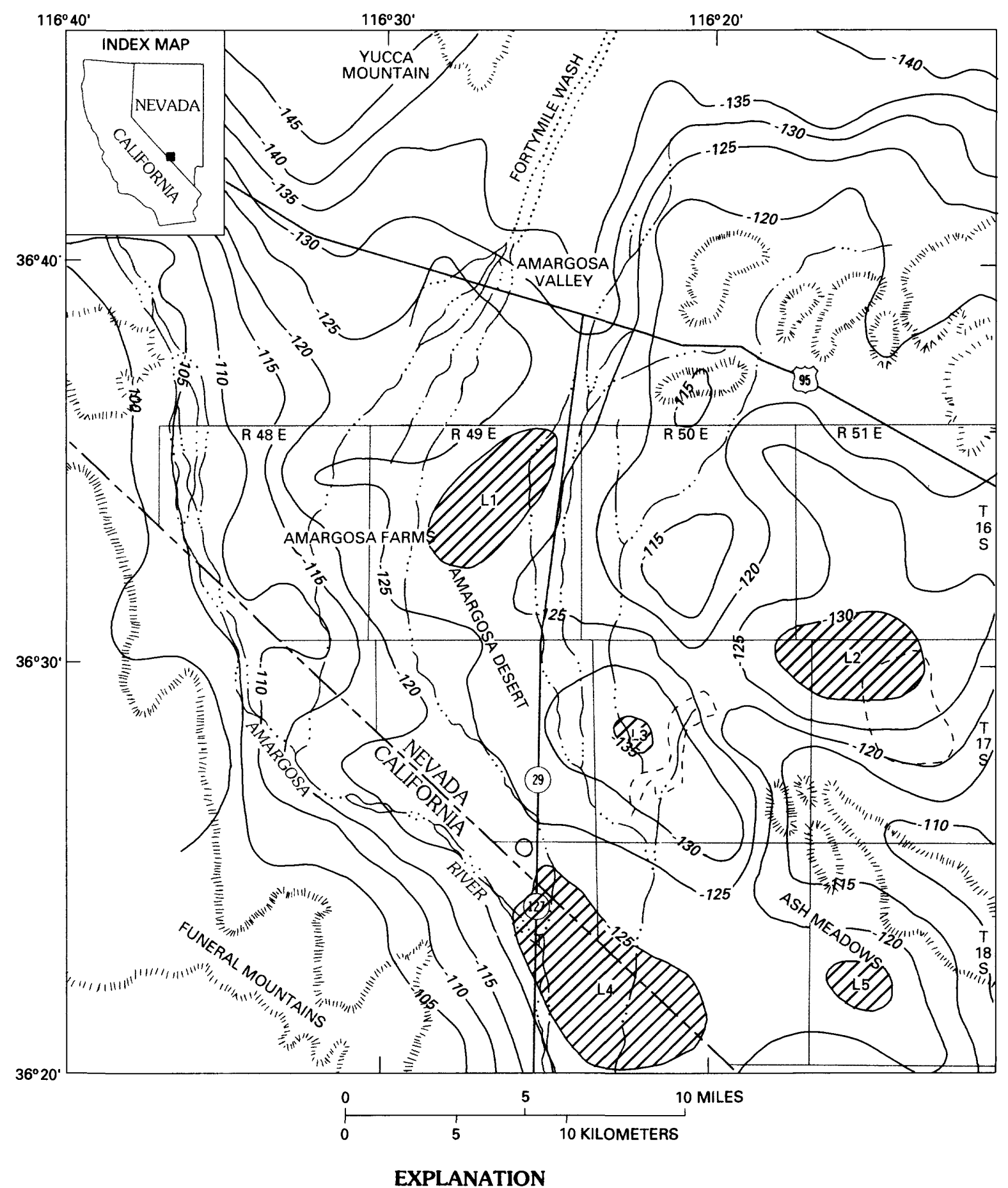

비,

:- - , MARSH OR PLAYA AREA

L1. GRAVITY LOWS DISCUSSED IN TEXT

$-120-$ LINE OF EQUAL COMPLETE BOUGUER
GRAVITY--Interval is 5 milligals

Figure 10.--Bouguer gravity in study area

(modified from Healey and others, 1980). 
As the degree of consolidation increases, however, this trend is reversed in a rather complicated process. Smaller bulk densities result in lower gravity potentials for equivalent thicknesses of alluvial sediments. Therefore, two controlling factors affect the gravitational response: (1) Alluvial thickness and (2) bulk density of the alluvium. Gravity lows L2 through L4 seem to be affected by both of these factors, and the degree of each is inseparable.

The spacing of gravity stations determines, to a large extent, an interpreter's ability to assign the effect of the factors controlling gravity readings. Station spacings for the work of Healey and others (1980) typically are slightly too far apart for this effort to be considered a detailed survey. This makes the effects of factor (1) appear predominant over those of factor (2), and consequently renders uncertain interpretations of lateral density differences in the alluvium. Also, intra-alluvial contrasts generally are more difficult to detect in all gravity studies than contrasts between bedrock and alluvium. Perhaps because of these problems, Healey and Miller (1971) concentrated on using their data to interpret the depth of valley-fill material. Here also a limitation existed in that they had no density values from the Amargosa Desert alluvium and, therefore, Healey and Miller (1971) substituted determinations from Yucca Flat, located to the north, when calculating alluvial thickness. This substitution may explain why their thickness values differed from those of the VES surveys. Healey and Miller (1971) also had no information about the degree of consolidation of valley sediments.

\section{Vertical Electric Sounding (VES) Resistivity Data}

The center points of Schlumberger ${ }^{1}$ VES survey electrode arrays from Greenhaus and Zablocki (1982) are shown in figure 11. A graphical representation of a VES profile is presented in figure 12, with values of resistivity plotted horizontally and depths below land surface plotted vertically. The dots in figure 12 represent observed apparent-resistivity values plotted against one half of the horizontal distance between outermost electrodes $(\mathrm{AB} / 2)$ of the Schlumberger array; the step function shows layers of various thicknesses and resistivities calculated by an interpretation program developed by Zohdy (1973, 1974, 1975) and used to create a layered model from the onsite observed values. The average transverse resistivity, $R$, was calculated as

$$
R=\frac{\sum_{i=1}^{n} r_{i} t_{i}}{\sum_{i=1}^{n} t_{i}},
$$

where $r_{i}=$ the resistivity of layer $i$,

$t_{i}=$ the thickness of layer $i$, and

$\mathbf{n}=$ the total number of layers in the profile for a specific station.

${ }^{1}$ The use of brand, trade, or firm names in this report is for identification purposes only and does not constitute endorsement by the U.S. Geological Survey. 


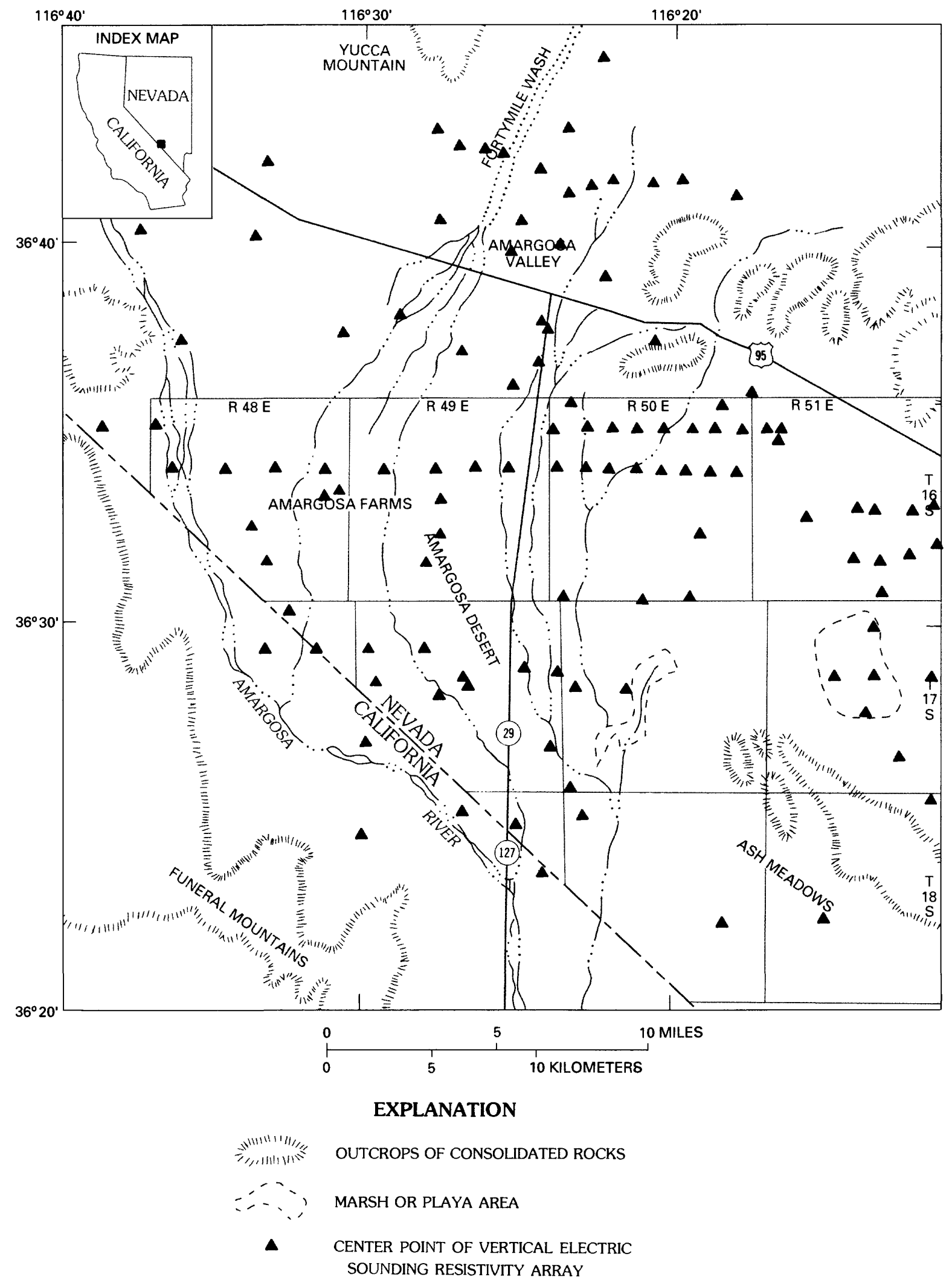

Figure 11.--Center points of Schlumberger-array vertical electric soundings (Greenhaus and Zablocki, 1982). 


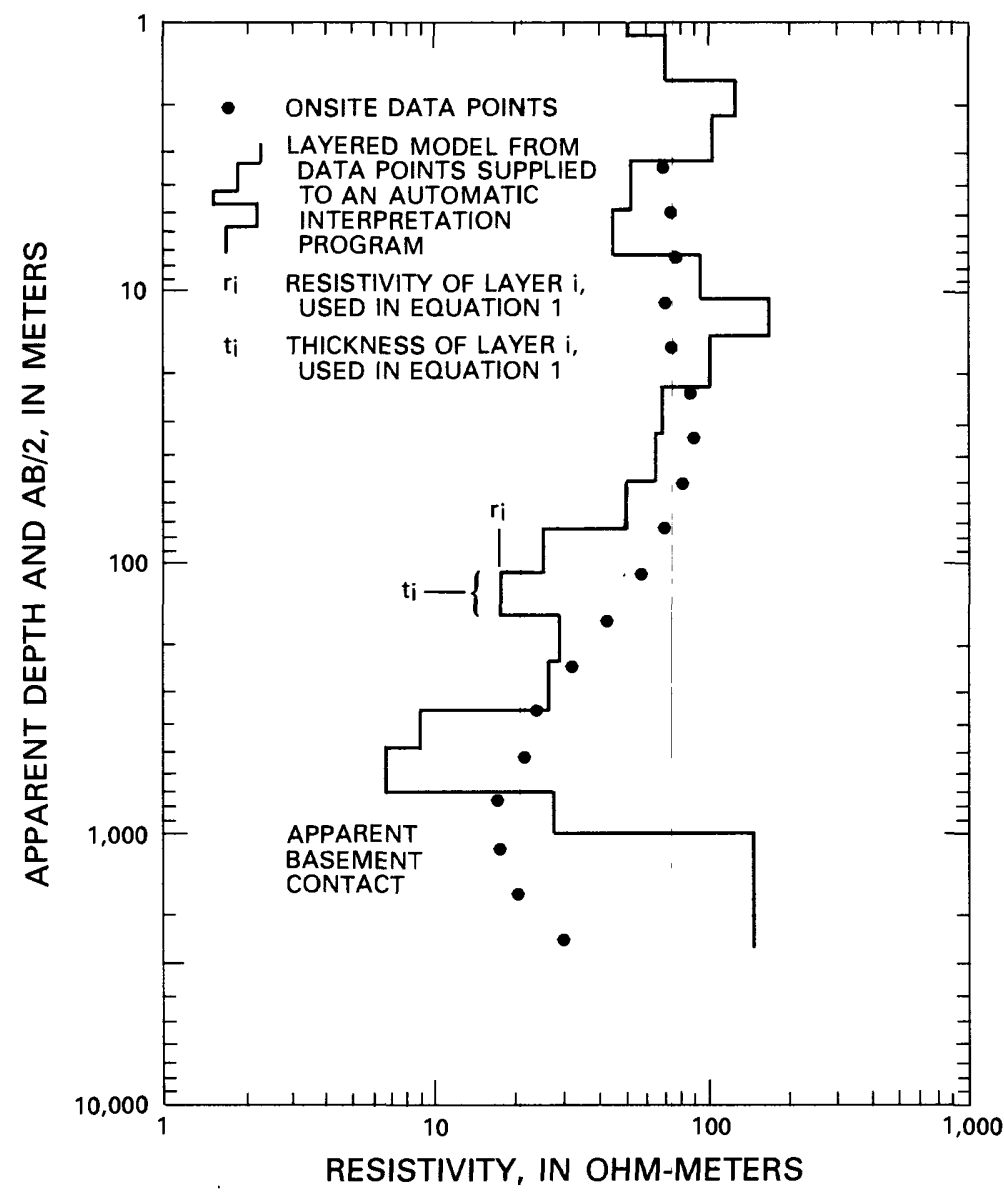

Figure 12.--Typical vertical electric sounding profile showing interpolated resistivity compared to depth.

Resistivity of alluvium is controlled, in the order of importance, by: (1) The salinity of the ground water, (2) the degree of saturation (Keller and Frischknecht, 1966), and (3) the electrical conductivity of the mineral grains. The Paleozoic (?) basement should have a substantially larger resistivity than the overlying sediments. Data on concentrations of sodium in ground water is shown in figure 13. These values were derived from analyses of water from wells that have depths similar to those of the wells supplying the data for fraction of coarse-grained sediments (fig. 5). Sodium was chosen because it adequately represents the general ground-water quality in the study area. Sodium is from two to three times as concentrated in the extreme west of the study area as in the center. Dissolved-solids values are all fairly smal1, and most of the water is potable. The degree of saturated porosity is affected by the thickness of the alluvium (fig. 14), the depth to ground.water (fig. 15), and geologic characteristics such as grain size and consolidation of the alluvium. Across the study area, the unsaturated zone as a percentage of the alluvial thickness varies by factors of about two to about five. It is never more than 15 percent of the column. The conductivity of the mineral grains is a minor control, relative to the other two. Averaged resistivity throughout the study area varies by a factor of about eight. 


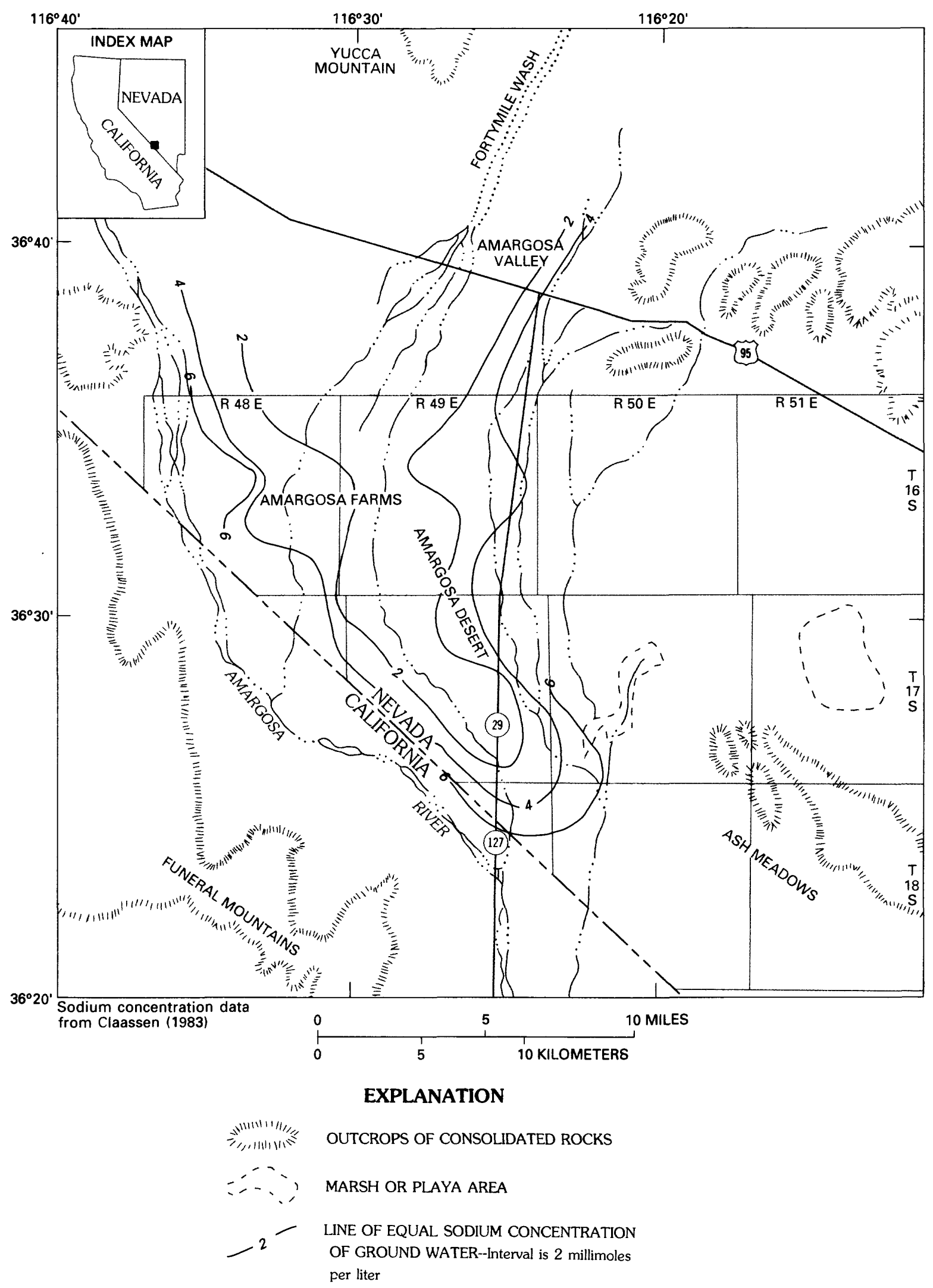

Figure 13.--Sodium concentrations in ground water (1960 through 1981). 


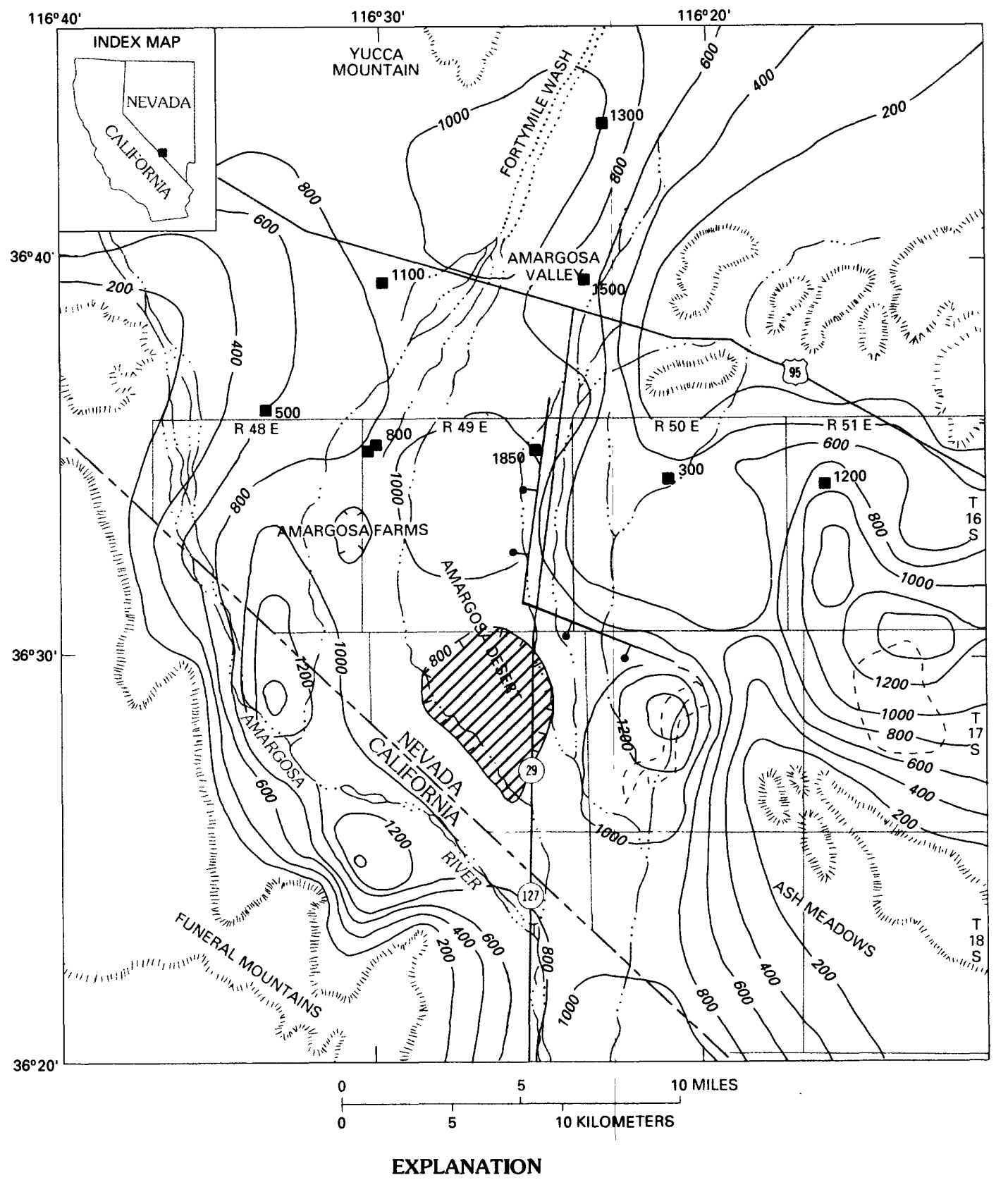

\footnotetext{
洋,

‥-

PD area of possible subsurface basalt

1000 - LINE OF EQUAL THICKNESS OF ALLUVIUM--

Interval is 200 meters (resistivity point data

from Greenhaus and Zablocki, 1982)

- 300 DEPTH TO BASEMENT ROCK FROM SEISMIC-

REFRACTION SURVEY lestimated from W.D.

Mooney and S.G. Schapper. written commun.

1989)

FAULT--Bar and ball on downthrown side (inferred
from gravity and electrical data)
}

Figure 14.--Apparent alluvial thickness from vertical electric sounding resistivity surveying. 


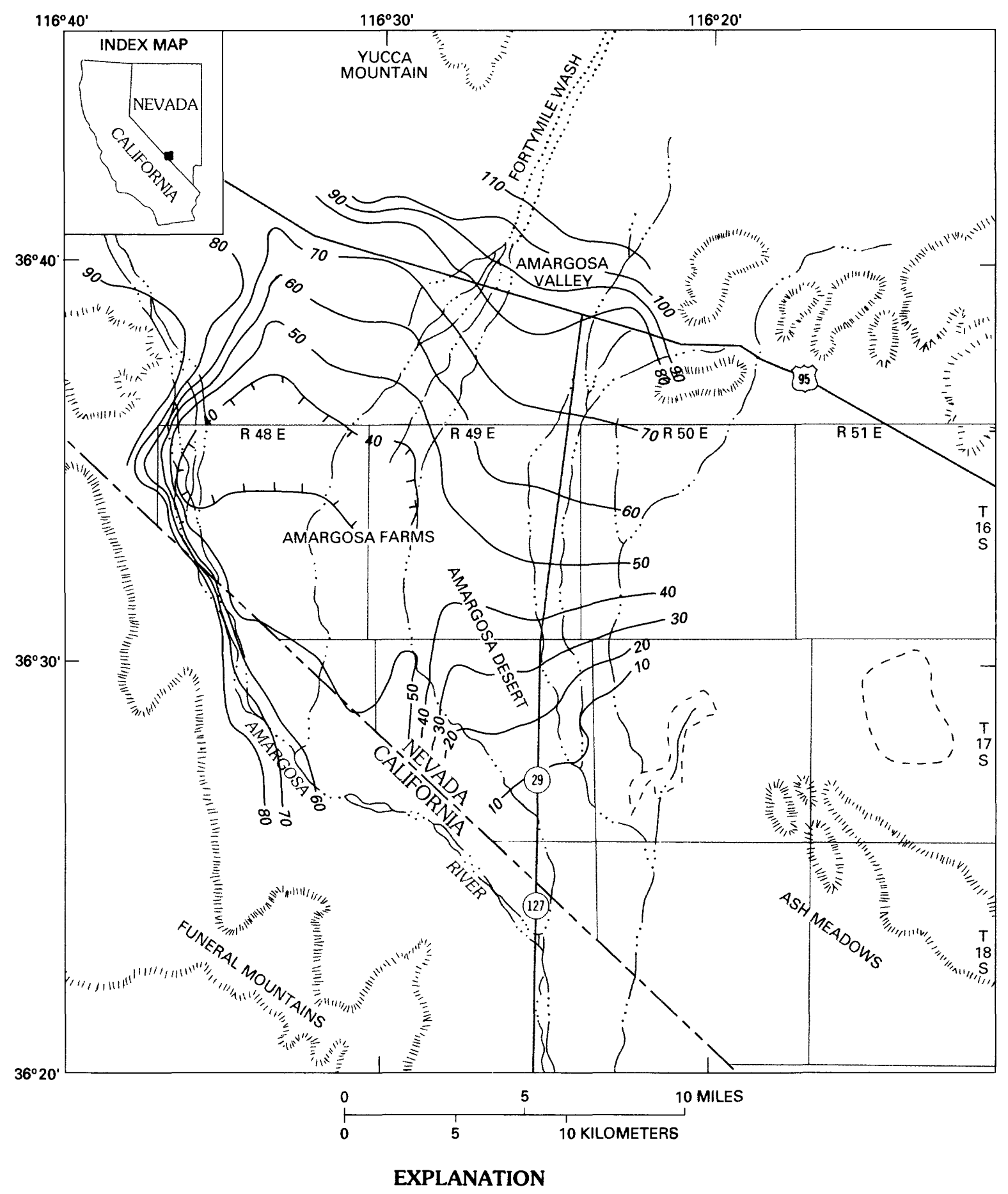

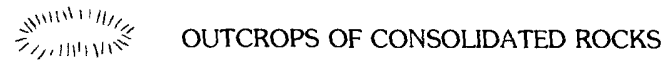

:- - MARSH OR PLAYA AREA

- 50 - LINE OF EQUAL DEPTH TO GROUND

WATER--Interval is 10 meters

Figure 15.--Depth to ground water. 
Average transverse resistivity for each station was shown contoured in figure 16. The smallest resistivity values, shown as RL in figure 16, occur near the smallest fractions of coarse-grained sediments (T.17S., R.50E.). However, at areas that have larger fractions of coarse-grained sediments (in T.16S., R.49E. and at the resistivity high, $\mathrm{RH}$, on the extreme western edge of the study area), small and large resistivity values occur. The tongue of small resistivity values extending north in the center of figure 16 is unexpected. Its geometry is the reverse of that of the grain-size contours in figure 7 and is unexplained by other data that will be discussed further in the analysis of combined data sets.

\section{Apparent Alluvial Thickness}

Previous studies (Walker and Eakin, 1963; Naff, 1973; Winograd and Thordarson, 1975) indicated the presence of a distinct stratigraphic discontinuity between valley-fill alluvium and underlying Paleozoic (?) or Precambrian (?) basement rocks beneath the Amargosa Desert. This inference is consistent with the structure of valleys within the Basin and Range province and is an important underlying assumption for interpreting VES resistivitydepth profiles used to determine the contact between alluvium and basement rock.

Alluvial thickness (or depth to basement rock) throughout the study area was estimated by Greenhaus and Zablocki (1982) by examining each resistivitydepth profile (for example, fig. 12, this report), and selecting the depth at which resistivity values increased sharply. This depth represented the approximate location of the contact between the overlying alluvium and the underlying basement rocks. Implicit in this interpretation is the assumption that the basement rock (which may be limestone, dolomite, quartzite, or argillite) has a much larger resistivity value than the deep alluvium. A criterion in selecting the depth of this contact was the point of inflection toward larger resistivity values, where a curve through the onsite resistivity values makes approximately a $45^{\circ}$ angle with the vertical axis (fig. 12). This point represents the apparent basement contact. Contours of alluvial thickness, inferred from the depths of these stratigraphic contacts (Greenhaus and Zablocki, 1982, fig. 2), are shown in figure 14.

At a few VES stations, no distinct contact could be determined between the alluvium and basement rock. This possibly resulted from a fractured basement-rock surface, with alluvium filling the fracture spaces, which rendered the contact electrically indistinct (Greenhaus and Zablocki, 1982). Also, at one location (T.17S., R.49E. in fig. 14), the apparent alluvial thickness, derived from resistivity-depth profiles, may be too small; the presence of a shallow, thick, basalt unit interbedded within the alluvium may be responsible for the anomalously thin sediments interpreted there. Drillers' logs of nearby drillholes confirm the presence of a basalt unit at $192 \mathrm{~m}$ at this location; the thickness of this basalt unit is unknown because the drillholes were terminated within it. However, basalt units described in other drillers' logs were no more than $23 \mathrm{~m}$ thick. Aeromagnetic-survey results (Greenhaus and Zablocki, 1982) were consistent with the presence of a basalt unit at this location. The absence of a pronounced gravity gradient (fig. 10) at this location (T.17S., R.49E.) indicates that the alluvial thickness should be between 900 and $1,000 \mathrm{~m}$. 


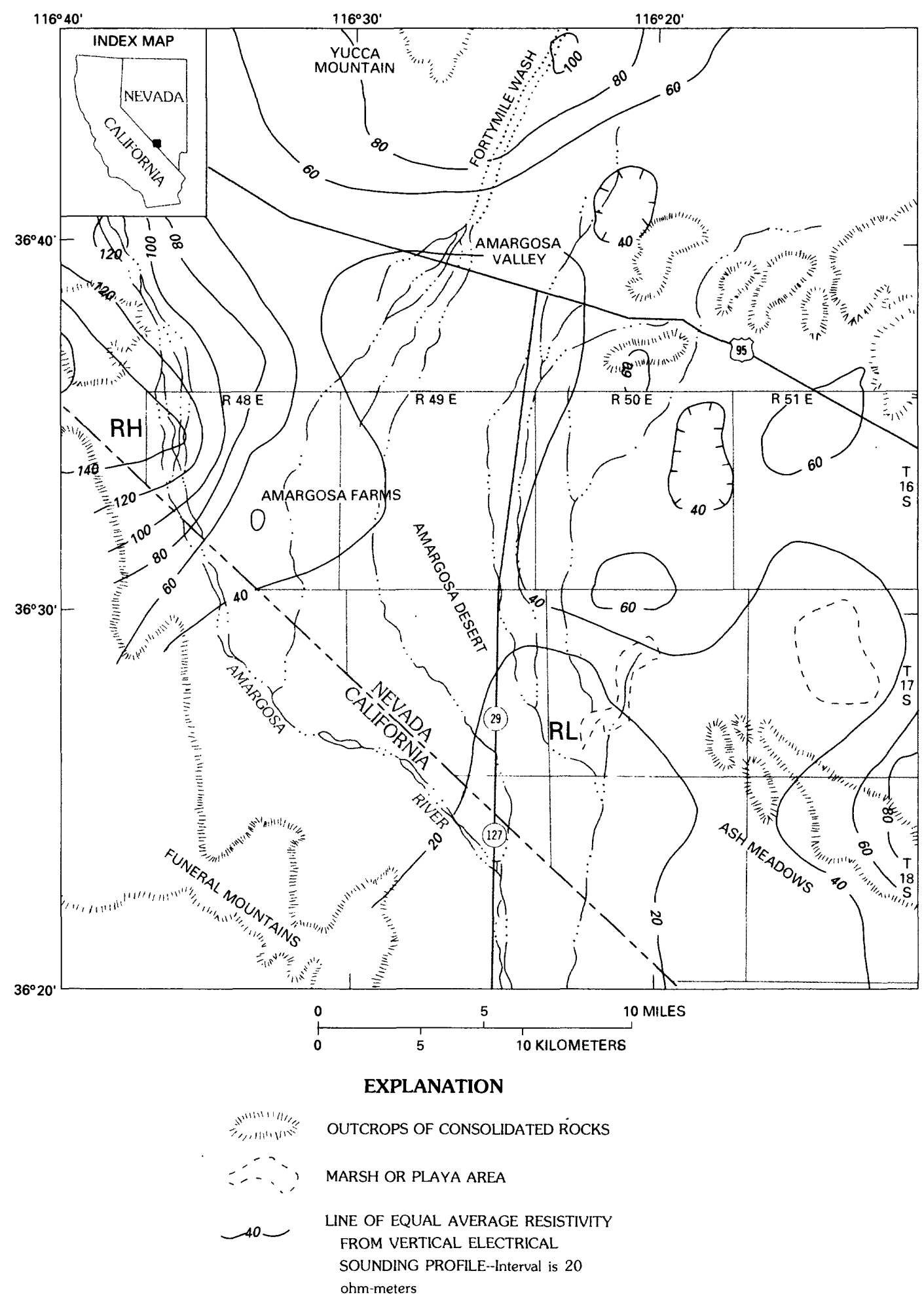

RH RESISTIVITY HIGH

RL RESISTIVITY LOW

Figure 16.--Average transverse resistivity based on vertical electric sounding profiles. 
The largest alluvial thicknesses occur in the southeastern part of the study area (T.17S., R.50E. in fig. 14), coincident with gravity lows L2 and L3 (fig. 10). A slightly greater than average depth of alluvium also is located at gravity low L1 (T.16S., R.49E.). The VES survey results indicated very thick sediments along the northeastern flank of the Funeral Mountains coincident with a steep gravity gradient in the area. The smallest alluvial thicknesses are located in the western part of the study area, coincident with the largest resistivity values and the most saline ground water (fig. 16). A major normal fault in the center of the study area, mentioned in various studies, is confirmed by the resistivity and gravity data (figs. 14 and 10). This fault probably is a barrier to ground-water flow (Czarnecki and Waddell, 1984). Partial confirmation of alluvial-thickness values also was provided by data from recent seismic-refraction surveys (W.D. Mooney and S.G. Schapper, written commun., 1989). Data from these seismic surveys are shown as point data in figure 14.

\section{Average Resistivity Values for the Upper 75 Meters of Alluvium}

Additional analyses were done on the resistivity data from the resistivity-depth profiles of Greenhaus and Zablocki (1982). In these analyses, equation 1 was used to calculate average resistivity values for the upper $75 \mathrm{~m}$ of the resistivity-depth profiles. This depth is approximately that of most of the water wells from which alluvial grain-size data was obtained. These results are shown as contours in figure 17.

Resistivity contour patterns in figure 17 resemble contour patterns of sodium concentrations (fig. 13). This pattern resemblance is expected because large resistivity values correspond to small sodium concentrations, or salinities. The converse also is true.

The trough-like pattern of the contours of sodium concentration (fig. 13) coincides with the ephemeral stream channels and distributaries of Fortymile Wash, the probable source of infiltrated, less-saline ground water. As the ground water flows downgradient toward the south and southeast, its salinity increases as its increased flow-path length enables it to contact more and more alluvium, dissolving salts and minerals as it flows.

The larger values of resistivity in the northern part of the study area (fig. 17) probably are caused partly by some increases in unsaturated alluvial thickness, in addition to the less-saline ground water located in the north. The unsaturated alluvial thickness for part of the study area, estimated from simulated depths to ground water, is shown in figure 15 .

Contour patterns of the fraction of coarse-grained sediments in the upper alluvium (fig. 5) resemble contour patterns of sodium concentrations in the ground water (fig. 13) and the average resistivity values for the upper $75 \mathrm{~m}$ of the alluvium (fig. 17). Coarse-grained sediments have less surface area than fine-grained sediments and, therefore, provide less surface area for dissolution of rock minerals by ground water. 


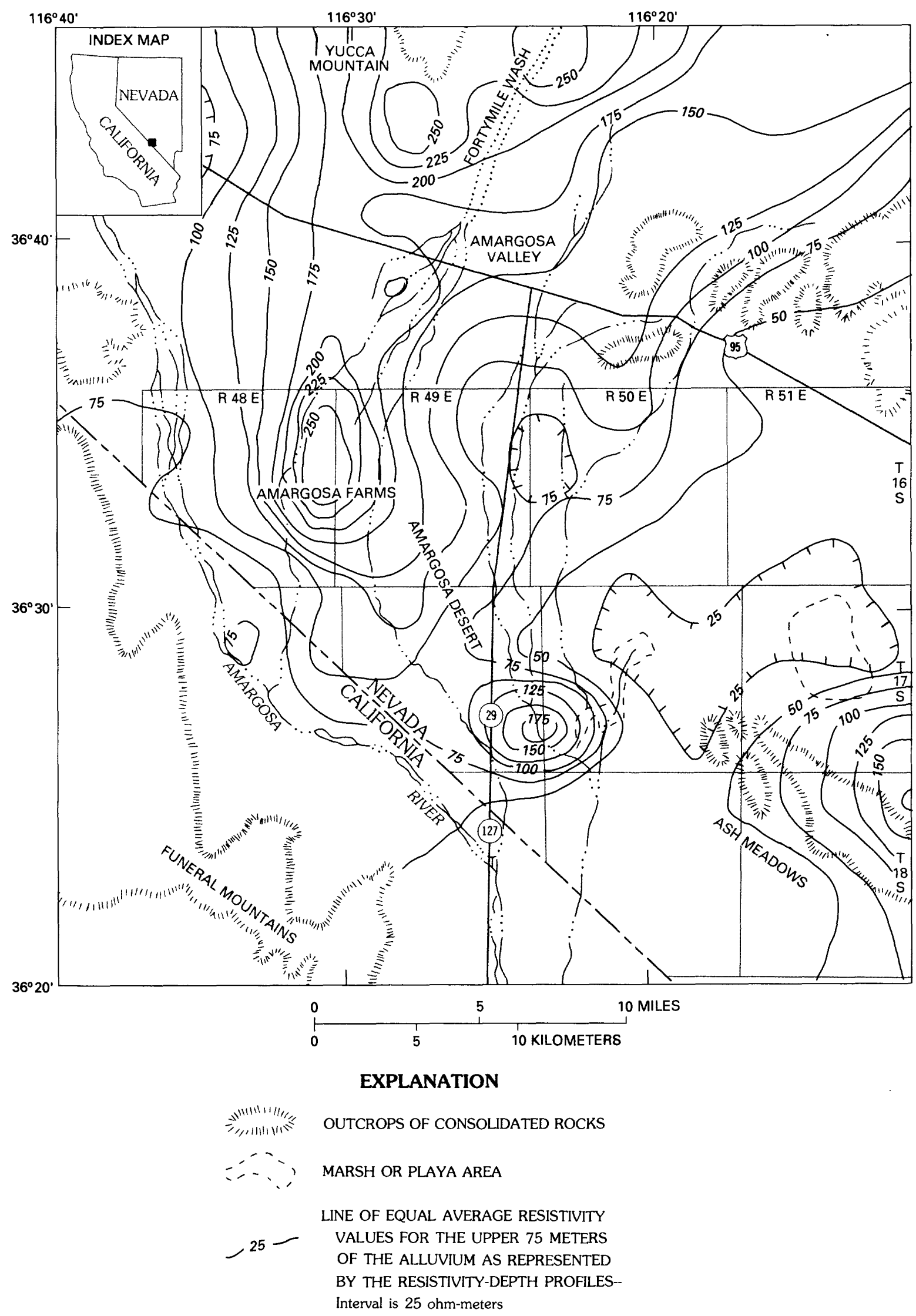

Figure 17.--Average transverse-resistivity values for the upper 75 meters of the alluvium as represented by the resistivity-depth profiles. 


\section{INFERRED HYDROGEOLOGIC FRAMEWORK}

The VES study of Greenhaus and Zablocki (1982) had the most promising geophysical information for helping to understand the ground-water flow system. The average resistivity throughout the total depth of each VES profile (fig. 16) seems to be unrelated to the fraction of coarse-grained sediments at the surface, based on drillers' logs (figs. 5 and 7). Grain size affects the porosity of subsurface strata. Although porosity is not the dominant factor controlling resistivity, this absence of a relation between resistivity and the fraction of coarse-grained sediments at the surface would seem to indicate that a different grain-size distribution exists in the upper and lower parts of the alluvium. This hypothesis is supported if one considers the resistivity of the upper $75 \mathrm{~m}$ of sediments (fig. 17), which indicates a closer relation to the fraction of coarse-grained sediments in the upper alluvium, and to the sodium concentrations of water sampled from the same interval. The resistivity of the entire alluvial column seems to be unrelated to these ground-water quality values. This, by itself, would indicate different ground-water quality in the upper and lower alluvium, because water quality is the controlling factor on resistivity. Unfortunately, the shallow wells that were sampled did not provide water-quality data on the deep ground water. The resistivity of the entire alluvial column compares fairly well with gravity data; the resistivity of the upper $75 \mathrm{~m}$ does not.

The interpretation of the VES data is affected, like that of gravity data, by some degree of uncertainty. Resistivity values from the VES survey vary widely at many stations, and depths to apparent basement contact are somewhat imprecise. Nonetheless, anomalies in the resistivity values averaged from land surface to basement rocks ought to be related to hydrogeologic characteristics of material in that space.

Because water quality is the primary factor affecting the resistivity of alluvium, the lobe of the $40 \mathrm{ohm}-\mathrm{m}$ contour extending northward toward the Fortymile Wash drainage in figure 16 is the most noteworthy of these anomalies. Sediments in this area are unconsolidated and, at the surface, coarse. Depths to ground water increase northward toward Amargosa Valley (fig. 15). Relatively fresh ground water flows down from Fortymile Wash toward the State line (fig. 13). Larger resistivity values would be expected for this combination of a thicker unsaturated zone and fresher water. For the smal1 resistivity averages shown in figure 16 to occur, the deeper ground water probably would need substantially more dissolved solids. Claassen (1983) hypothesizes such a model. Ground water that has large concentrations of dissolved solids and is located near the surface along the State line (fig. 13) may result from ground-water flow that is forced upward by an extension of a shallow Tertiary confining bed described by Naff (1973). If deeper water is enriched in dissolved solids, its mixing with upper water would yield the larger sodium concentrations that occur along the State line. However, the VES profiles do not clearly indicate the presence of any

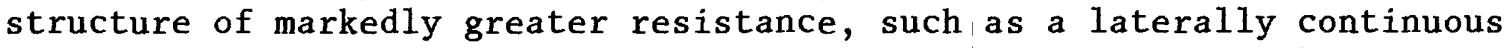
barrier near the surface, which extends to depth. The possibility exists that deeper ground water is forced up by a trend of increasing consolidation to the south, rather than by a specific structure. 
A resistivity high, $\mathrm{RH}$ (fig. 16), represents another major anomaly because the largest measured average resistivity values were obtained near wells that produced ground water that had some of the largest concentrations of dissolved solids. However, surface sediments near these wells are coarse grained (fig. 5), which would result in somewhat larger resistivities. Coarse sediments may be present down to basement rocks in this area near the present channel of the Amargosa River, and fresher water may occur deeper in the sediments. Depths to ground water also increase in this western part of the study area, and this could contribute to increased values of resistivity.

Analysis of the VES data yielded alluvial-thickness values that indicate the thickest sediments at gravity lows L2 and L3 (fig. 10); these resistivitydetermined values probably are more accurate than thickness determinations based on gravity data. Gravity low, L1, is located in an area where the valley fill is thicker than average. The analysis of resistivity data also indicated a deep trough of sediments along the flank of the Funeral Mountains (fig. 14). The northeastern wall of this trough is along the State line, and may be an expression in the basement topography of Naff's (1973, p. 26) Tertiary confining bed, extended farther northwest than possible because of the scope of his study (Naff, 1973). Healey and Miller (1971) had reported pre-Cenozoic outcrops in T.16S., R.48E., and these may be surface evidence of such an extended barrier. They also inferred a high-angle fault along the State line, downthrown to the west, and a partially buried pre-Cenozoic ridge near Naff's Tertiary confining bed.

\section{CONCLUSIONS}

Descriptions of alluvial material reveal that the alluvium cannot be readily subdivided into correlative stratigraphic units. These descriptions provide some approximate grain-size data showing a tongue of coarse-grained surface material extending southward into the middle of the study area. This material is coincident with fresher, shallow ground water. Near-surface ground-water traveltime may be less in this area. Drillers' logs, generally, expose a trend in consolidation of sediments increasing from north to south.

Gravity lows generally correspond to thicker alluvium. A previously discovered normal fault in the center of the study area was corroborated by alluvium-thickness analysis of a vertical electric sounding (VES) survey. Resistivity lows occur near the smallest fractions of coarse-grained sediments. However, a systematic relation of surface grain size to average resistivity of the total alluvial depth is not discernable. Large values of resistivity in the upper 75 meters of alluvium coincide with fresher shallow ground water. Without more information on grain size or water quality at depth, interpretation of the average resistivity of the up to 1,400 meters of alluvium is uncertain. It is probable that distributaries of the Fortymile Wash drainage in the central part of the study area supply relatively fresh ground water that overlies a substantially more saline ground water at depth. This model may represent the whole study area. The two types of ground water may have different origins or simply may have originated from different flow-path lengths and traveltimes. 
Recent and planned drilling in the Amargosa Desert may provide additional lithologic, stratigraphic, and hydrochemical data for refining the conclusions in this report. Additional information is needed about the density of sediments overlying the basement. Gravity determinations have been based on densities of rocks and alluvium from the Nevada Test Site, many kilometers to the north. Inferences from resistivity data would be greatly strengthened by information on water quality at depth.

\section{SELECTED REFERENCES}

Carr, W.J., 1984, Regional structural setting of Yucca Mountain, southwestern Nevada, and late Cenozoic rates of tectonic activity in part of the southwestern Great Basin, Nevada and California: U.S. Geological Survey Open-File Report 84-854, 109 p.

Claassen, H.C., 1983, Sources and mechanisms of recharge for ground water in the west-central Amargosa Desert, Nevada--A geochemical interpretation: U.S. Geological Survey Open-File Report 83-542, 66 p.

Czarnecki, J.B., 1985, Simulated effects of increased recharge on the groundwater flow system of Yucca Mountain and vicinity, Nevada-California: U.S. Geological Survey Water-Resources Investigations Report 84-4344, $38 \mathrm{p}$.

Czarnecki, J.B., and Wadde11, R.K., 1984, Finite-element simulation of groundwater flow in the vicinity of Yucca Mountain, Nevada-California: U.S. Geological Survey Water-Resources Investigations Report 84-4349, $38 \mathrm{p}$.

Dobrin, M.B., 1976, Introduction to geophysical prospecting (3d ed.): New York, McGraw-Hill, $630 \mathrm{p}$.

Denny, C.S., and Drewes, Harald, 1965, Geology of the Ash Meadows quadrangle, Nevada-California: U.S. Geological Survey Bulletin 1181-I, 56 p.

Freeze, R.A., and Cherry, J.A., 1979, Groundwater: Englewood Cliffs, N.J., Prentice-Ha11, $604 \mathrm{p}$.

Greenhaus, M.R., and Zablocki, C.J., 1982, A Schlumberger resistivity survey of the Amargosa Desert, southern Nevada: U.S. Geological Survey OpenFile Report 82-897, 151 p.

Hay, R.L., Pexton, R.E., Teague, T.T., and Kyser, T.K., 1986, Spring-related carbonate rocks, $\mathrm{Mg}$ clays, and associated minerals in Pliocene deposits of the Amargosa Desert, Nevada and California: Geological Society of America Bulletin, v. 97, p. 1488-1503.

Healè, D.L., and Miller, C.H., 1971, Gravity survey of the Amargosa Desert area of Nevada and California: U.S. Geological Survey Report USGS-474-136, 29 p. [Available from National Technical Information Service, U.S. Department of Commerce, Springfield, VA 22161.]

Healey, D.L., Wahl, R.R., and Oliver, H.W., 1980, Death Valley Sheet, in The collection Complete Bouguer gravity map of Nevada: Reno, University of Nevada, Nevada Bureau of Mines and Geology, map 69, scale 1:250,000, 1 sheet.

Hoover, D.L., Swadley, W.C., and Gordon, A.J., 1981, Correlation characteristics of surficial deposits with a description of surficial stratigraphy in the Nevada Test Site region: U.S. Geological Survey Open-File Report $81-512,27 \mathrm{p}$.

Keller, G.V., and Frischknecht, F.C., 1966, Electrical methods in geophysical prospecting: New York, Pergamon Press, 517 p. 
Moench, R.H., 1965, Structural geology of the southern part of the Amargosa Desert and vicinity: U.S. Geological Survey Report USGS 474-253, 21 p. [Available from National Technical Information Service, U.S. Department of Commerce, Springfield, VA 22161.]

Naff, R.L., 1973, Hydrogeology of the southern part of the Amargosa Desert in Nevada: Reno, University of Nevada, unpublished Master's thesis, $207 \mathrm{p}$.

Naff, R.L., Maxey, G.B., and Kaufman, R.F., 1974, Interbasin ground-water flow in southern Nevada: Reno, University of Nevada, Nevada Bureau of Mines and Geology Report 20, $28 \mathrm{p}$.

Skrivan, J.A., and Karlinger, M.R., 1980. Semi-variogram estimation and universal Kriging program: 98 p. [Available from National Technical Information Service, U.S. Department of Commerce, Springfield, VA 22161 as $\mathrm{PB}-81$ 120560.]

Spaulding, W.G., 1985, Vegetation and climates of the last 45,000 years in the vicinity of the Nevada Test Site, south-central Nevada: U.S. Geological Survey Professional Paper 1329, 83 p.

Swadley, W.C., 1983, Map showing surficial geology of the Lathrop Wells quadrangle, Nye county, Nevada: U.S. Geological Survey Miscellaneous Investigations Series Map I-1361, scale 1:48,000, 1 sheet.

Walker, G.E., and Eakin, T.E., 1963, Geology and ground water of Amargosa Desert, Nevada-California: Nevada Department of Conservation and Natural Resources Ground-Water Resources--Reconnaissance Series Report 14, 45 p.

Winograd, I.J., and Thordarson, William, 1975, Hydrogeologic and hydrochemical framework, south-central Great Basin, Nevada-California, with special reference to the Nevada Test Site: U.S. Geological Survey Professional Paper 712-C, 126 p.

Zohdy, A.A.R., 1973, A computer program for the automatic interpretation of Schlumberger sounding curves over horizontally stratified media: 25 p. [Available from National Technical Information Service, U.S. Department of Commerce, Springfield, VA 22161 as PB-232 703/AS.] 1974, Use of Dar Zarrouk curves in the interpretation of vertical electrical sounding data: U.S. Geological Survey Bulletin 1313-D, 41 p. 1975, Automatic interpretation of Schlumberger sounding curves using modified Dar Zarrouk functions: U.S. Geological Survey Bulletin 1313-E, $39 \mathrm{p}$. 